\title{
Comparative assessment of corrosion of concrete reinforced with unprotected steel and hot-dip galvanized steel
}

\author{
Evaluación Comparativa de la corrosión del hormigón armado con acero sin protección y del acero \\ galvanizado en inmersión en caliente
}

Vinícius de Kayser Ortolan (Main author)

itt Performance, Technological Institute - UNISINOS

Avenida Unisinos, 950, São Leopoldo, Rio Grande do Sul (Brazil)

vortolan@unisinos.br

\section{Thayse Hilgert}

Department of Civil Engineering- UNISINOS

Avenida Unisinos, 950, São Leopoldo, Rio Grande do Sul (Brazil)

\section{Juan José Howland}

Instituto Superior Politécnico "Jose Antonio Echeverría" (CUJAE / ISPJAE)

Marianao, La Habana (Cuba)

\section{Luis Silva}

Departamento de Engenharia Civil e Ambiental - Universidad de la Costa (Colombia)

Barranquilla (Colombia)

\section{Bernardo Fonseca Tutikian (Corresponding author)}

itt Performance, technological Institute - UNISINOS

Avenida Unisinos, 950, São Leopoldo, Rio Grande do Sul (Brazil)

Departamento de Engeniería Civil y Ambiental - Universidad de la Costa (Colombia)

btutikian@unisinos.br

Manuscript Code: 654

Date of Acceptance/Reception: 23.07.2017/18.06.2015

DOI: $10.7764 /$ RDLC.16.2.238

\begin{abstract}
Increasing the lifespan of structures is of great importance for civil construction, either because of economic aspects or security to the users. Corrosion of reinforcement is one of the most recurring problems, especially in environments with high chloride content. One of the most effective alternatives to protect reinforcement against corrosion is the hot-dip galvanizing of steel bars, with the addition of a zinc coating that is consumed before steel entering in reaction. In this paper, it was investigated the comparison between unprotected steel bars and hot-dip galvanized ones, immersed in four types of concrete with different water/cement ratio, and subjected to accelerated corrosion test executed by the CAIM procedure. It was observed corrosion decreased for all types of concrete, reaching $70.5 \%$ of reduction for the richest mixture, showing that the hot-dip galvanizing may be an important alternative to the wired concrete structures, particularly when used in combination with mixtures of greater durability.
\end{abstract}

Key words: Reinforcement corrosion; hot-dip galvanizing; adhesion; bending test.

Resumen

El aumento de la vida útil de las estructuras es de gran importancia para la construcción civil, sea por razones económicas o de seguridad de los usuarios. La corrosión de refuerzo es uno de los problemas más recurrentes, especialmente en entornos con alto contenido de iones cloruro. Una de las alternativas más eficaces para proteger el refuerzo contra la corrosión es la galvanización en caliente de barras de acero, con la adición de recubrimiento de zinc que se ingiere antes del acero entrar en reacción. En este trabajo, fue investigado la comparación entre las barras de acero sin protección y las galvanizadas en caliente, inmersas en cuatro tipos de hormigón con diferentes relaciones agua/cemento, y se somete a procedimiento de ensayo de corrosión acelerada ejecutado por el método CAIM. Se observó la disminución de la corrosión para todos los tipos de hormigón, alcanzando el 70,5\% de la reducción de la muestra más rica, mostrando que el galvanizado por inmersión en caliente puede ser una alternativa importante para las estructuras de hormigón, especialmente cuando se utiliza en combinación con mezclas de mayor durabilidad.

Palabras clave: Corrosión de la armadura; galvanizado por inmersión en caliente; adhesión; ensayo de flexión.

\section{Introduction}

According to NBR 15575 (ABNT, 2013), the lifespan of reinforced concrete in Brazil, for residential buildings, must be at least 50 years on the minimum level, or 63 and 75 years on upper levels, guided by other international standards (Pacheco, 2016). On the other hand, BS 7543 stipulates 120 years of lifespan for works of art such as bridges and viaducts 
and 60 years for new buildings and reformation of public buildings. Vayas \& Iliopoulos (2014) highlight, pursuant to EN 1992-2, that for bridges, as in works of art, it is established a life span of at least 100 years. Achieving these values is no easy task, especially if the maintenance process is not efficient or unwell planned. The corrosion of steel bars is one of the most recurrent pathological signs in steel-reinforced concrete structures (Figueiredo \& Meira, 2013; Verma, Bhadauri \& Akhtar 2014), especially those exposed to aggressive agents throughout its lifespan, such as chlorides and carbon dioxide, found in abundance in large cities and on the coast. Concrete structures have the potential to reach exceeding 50 years of lifespan; however, it has been observed that they are deteriorating prematurely. When reaching from ten to fifteen years, such structures require significant corrective action because of the reinforcement corrosion (Grochoski \& Helene, 2008).

In analytical models, the use of corrosion inhibitors for environments under action of chloride ion and carbon dioxide, exhibit optimum receptivity for increased failure time and safety of the reinforced concrete structure (Faustino, Brás \& Ripper, 2015; Poursaee 2016). In addition to benefiting and extending the life of the concrete structure, the use of corrosion inhibitors reduces the cost of living over the life of the concrete structure (Amaya, 2016).

According to Gonçalves, Andrade \& Castellote (1997), to protect the reinforced concrete structures it is possible to use the direct protection (on steel) and the indirect protection (on the concrete). The direct protection, in agreement with (Yeomens, 2004), have good performance in environment under action chlorides ions, because it protects the steel bars directly. For to decrease the porosity, Triana, Lizararazo-Marriaga \& Flórez (2013) suggest produce mixtures using concrete with substitution the cement by $20 \%$ of metakaolin, and exhibited much less corrosion the samples containing only cement. Still, Possan, Andrade (2014) considering the probalistic estimation through the conjoint application of reliability analysis and Markov Chains, the increase of cover is favorable to durability and increase the lifespan.

The direct protection is more efficient because it protects the steel bars directly. Among the types of direct protection, there is the impressed current cathodic system, the cathodic galvanic type, the physical barrier and the galvanic barrier. The first two have the disadvantage of requiring constant maintenance and the operation may be complex depending on the aggressiveness of the exposure environment. On the other hand, the physical barrier demands skilled labor force and it is preferably used in specific situations, due to the labor force required. For broader and more effective response, there is the galvanic barrier produced by hot-dip galvanizing of steel bars (Gonçalves, Andrade \& Castellote, 1997).

The hot-dip galvanized steel has great durability and that is the reason why its application in the market grows increasingly. Widely used in metal structures, it can also be an option for reinforced concrete structures (BaltazarZamora et al., 2012). The galvanization brings many advantages that go beyond the increasing of lifespan, such as reducing the risks of cracks caused by the steel expansion during the corrosion process, the rust stains and the concrete breakdown, due to a lower frequency and magnitude of the concrete repairs. Therefore, the initial cost to deploy such a system in reinforced concrete structures can be counterbalanced by the several advantages mentioned before. In Addition, galvanized reinforcement in poor quality concrete, the time of corrosion initiation as early as 14 months when exposed to an aggressive marine environment, in other hand, concrete with $\mathrm{w} / \mathrm{c}$ of 0,4 to 0,6 , the galvanized rebar remained passive throughout the two years (Maldonado, Pech-Canul \& Alhassan, 2006).

The galvanization is the process that creates a protective zinc film base to the steel, isolating the surface of the rod from the exposure environment. This protective film acts as the anode, with the steel acting as the cathode. Thus, being zinc more electronegative, it sacrifices itself, protecting steel from deterioration. The alloys formed between iron and zinc on the contact surface drive the coating to its integration to the metal base, so that, besides protecting the steel, zinc coating also allows the handling, transportation and installation of galvanized parts without causing damage to the surface (Yeomens, 2004).

According to (Yoo et al., 2011), in general the average thickness of zinc is sufficient to achieve the useful life of the structure without maintenance for long periods. Thus, according to Pannoni (2011), it is also possible to estimate the lifespan of the structure with the support of ISO 9223 (ISO, 2012) from the thickness of galvanizing, as shown in Table 1. 
Table 1. Indicatives rates of corrosion for different environmental. Source: ISO 9223:2012.

\begin{tabular}{|c|c|c|c|c|}
\hline \multirow[b]{3}{*}{$\begin{array}{l}\text { Corrosivity } \\
\text { category }\end{array}$} & \multicolumn{4}{|c|}{$\begin{array}{l}\text { Mass loss per unit of surface/loss of thickness } \\
\text { (after one year of exposition) }\end{array}$} \\
\hline & \multicolumn{2}{|c|}{ Low-carbon steel } & \multicolumn{2}{|r|}{ Zinc } \\
\hline & $\begin{array}{l}\text { Mass loss } \\
\left(\mathrm{g} / \mathrm{m}^{2}\right)\end{array}$ & $\begin{array}{l}\text { Thickness } \\
\text { loss }(\mu \mathrm{m})\end{array}$ & $\begin{array}{l}\text { Mass loss } \\
\left(\mathrm{g} / \mathrm{m}^{2}\right)\end{array}$ & $\begin{array}{c}\text { Thickness loss } \\
(\mu \mathrm{m})\end{array}$ \\
\hline $\mathrm{C} 1$ - very low & $<10$ & $<1.3$ & $<0.7$ & $<0.1$ \\
\hline C2-low & $>10$ a 200 & $>1.3$ a 25 & $>0.7$ a 5 & $>0.1$ a 0.7 \\
\hline C3-medium & >200 a 400 & $>25$ a 50 & $>5$ a 15 & $>0.7$ a 2.1 \\
\hline C4 - high & $>400$ a 650 & $>50$ a 80 & $>15$ a 30 & $>2.1$ a 4.2 \\
\hline C5 - very high & $>650$ a 1500 & $>80$ a 200 & $>30$ a 60 & $>2.1$ a 4.2 \\
\hline
\end{tabular}

Therefore, the aim of this paper is to compare the corrosion in reinforced concrete elements with steel bars of $12.5 \mathrm{~mm}$ diameter hot-dip galvanized and without galvanization, traditionally used in civil construction. The accelerated corrosion test in the reinforcement was done through the CAIM method, a method that has been tested and approved by many researchers (Graeff, 2007; Lima, 2005; Torres, 2006; Tutikian \& Ortolan, 2014). This test consists of immersing concrete elements in a solution with sodium chloride and imprints an alternating current forming a closed circuit. Four concrete mixtures for unprotected steel and galvanized steel were used, allowing the formation of dosage curves for both situations, besides the determination of behavioral equations and correlation coefficients, to verify the effectiveness of the experimental procedure.

\section{Materials and Methods}

\section{Materials}

The materials used in this research were the Portland pozzolanic CPIV cement, fine aggregate, coarse aggregate and potable water. All components were chosen because they are commercially available and widely used in construction.

Portland Cement. The specific mass of the Portland cement used was $\rho=3120 \mathrm{~kg} / \mathrm{m}^{3}$ determined as NM 23 (AMN, 2006), while the mechanical and chemical properties are detailed in Table 2.

\begin{tabular}{lc} 
Table 2. Chemical and mechanical composition of pozzolanic cement. Source: Self-elaboration. \\
\hline Mechanical properties & Results \\
\hline Sieve \#200 (75 mm) & 0.60 \\
Sieve \#325 (45 mm) & 4.68 \\
Blaine fineness (g/cm ${ }^{2}$ ) & 4503 \\
Early setting time (min) & 259 \\
End of setting time (min) & 338 \\
Compressive strength of 3 days (MPa) & 19.8 \\
Compressive strength of 7 days (MPa) & 24.7 \\
Compressive strength of 28 days (MPa) & 37.4 \\
Chemical properties & Results \\
Insoluble residue (\%) & 0.60 \\
Loss on ignition (\%) & 3.00 \\
MgO (\%) & 4.70 \\
SO3 (\%) & 2.30 \\
\hline
\end{tabular}

Aggregates. The fine aggregate used was extracted river sand, which had unit mass of $\rho=1580 \mathrm{~kg} / \mathrm{m}^{3}$, determined as recommended by NM 45 (AMN, 2006) and density of $\rho=2660 \mathrm{~kg} / \mathrm{m}^{3}$, as recommended by NM 52 (AMN, 2009). On the other hand, the coarse aggregate consists of crushed basaltic rock, presenting a unit mass of $\rho=1430 \mathrm{~kg} / \mathrm{m}^{3}$, as 
recommended by NM 45 (AMN, 2006). The density was determined in $\rho=26000 \mathrm{~kg} / \mathrm{m}^{3}$, by the hydrostatic balance method NM 53 (AMN, 2009).

The sieve analysis of the aggregates was performed according to NM 248 (AMN, 2001), which provides for the determination of particle size distribution of fine and coarse aggregates for concrete. The results are shown in Table 3.

\begin{tabular}{|c|c|c|c|c|}
\hline \multirow[b]{2}{*}{$\begin{array}{l}\text { Sieves } \\
(\mathrm{mm})\end{array}$} & \multicolumn{2}{|c|}{ Fine aggregate } & \multicolumn{2}{|c|}{ Course aggregate } \\
\hline & $\begin{array}{l}\text { Retained } \\
\text { mass (\%) }\end{array}$ & $\begin{array}{l}\text { Accumulated } \\
\text { retained mass } \\
(\%)\end{array}$ & $\begin{array}{l}\text { Retained } \\
\text { mass (\%) }\end{array}$ & $\begin{array}{c}\text { Accumulated } \\
\text { retained mass } \\
(\%)\end{array}$ \\
\hline \# 19 & 0 & 0 & 3 & 3 \\
\hline \# 12.5 & 0 & 0 & 51 & 54 \\
\hline \# 9.5 & 0 & 0 & 28 & 82 \\
\hline \# 6.3 & 0 & 0 & 17 & 99 \\
\hline \# 4.8 & 1 & 1 & 1 & 100 \\
\hline \# 2.4 & 4 & 5 & 0 & 100 \\
\hline \# 1.2 & 13 & 18 & 0 & 100 \\
\hline \# 0.6 & 30 & 48 & 0 & 100 \\
\hline \# 0.3 & 41 & 89 & 0 & 100 \\
\hline \# 0.15 & 10 & 99 & 0 & 100 \\
\hline $\begin{array}{l}\text { Bottom } \\
(<0.075)\end{array}$ & 1 & 100 & 0 & 100 \\
\hline $\begin{array}{l}\text { Fineness } \\
\text { modulus }\end{array}$ & \multicolumn{2}{|r|}{2.60} & \multicolumn{2}{|r|}{6.85} \\
\hline $\begin{array}{l}\text { Maximu } \\
\text { m size }\end{array}$ & \multicolumn{2}{|r|}{$4.8 \mathrm{~mm}$} & \multicolumn{2}{|c|}{$19.0 \mathrm{~mm}$} \\
\hline
\end{tabular}

\section{Method}

Concrete Dosages. For the preparation of the studied concrete, we used a mixture of Portland cement, fine aggregate, coarse aggregate and water. Dosages were prepared according to the IBRACON method (Tutikian \& Helene, 2011). The used traces were the rich (1:3), intermediate (1:4; and 1:5); and poor (1:6); with ideal mortar content fixed at 54\%, with a mixing time of five minutes and reduction of $100 \mathrm{~mm} \pm 20 \mathrm{~mm}$, determined according to the NM 67 (AMN, 1998).

The obtainment of the used traces comes from a w/c fixed bond, to optimize subsequent comparisons. Table 4 shows the traces for each $\mathrm{w} / \mathrm{c}$ ratio unit, according to the proposed method.

\begin{tabular}{|c|c|c|c|c|c|}
\hline \multirow[b]{2}{*}{ Composition } & \multicolumn{3}{|c|}{ Unit composition } & \multirow[b]{2}{*}{$\begin{array}{l}\mathrm{w} / \mathrm{c} \\
\text { ratio }\end{array}$} & \multirow[b]{2}{*}{$\begin{array}{c}\text { Slump test } \\
(\mathrm{mm})\end{array}$} \\
\hline & Cement & $\begin{array}{c}\text { Fine } \\
\text { aggregate }\end{array}$ & $\begin{array}{c}\text { Course } \\
\text { aggregate }\end{array}$ & & \\
\hline $1: 3$ & 1 & 1.16 & 1.84 & 0.30 & 100 \\
\hline $1: 4$ & 1 & 1.70 & 2.30 & 0.40 & 110 \\
\hline $1: 5$ & 1 & 2.24 & 2.76 & 0.50 & 90 \\
\hline $1: 6$ & 1 & 2.78 & 3.22 & 0.60 & 100 \\
\hline
\end{tabular}

Accelerated corrosion test - CAIM method. To achieve the research goal, the specimens for concrete testing were molded to compressive strength tests in the stipulated ages and prisms of concrete for conducting the test of accelerated corrosion CAIM.

To the CAIM test, it was defined the potential difference ( $d d p)$ imprinted in the system and the test time, according to the results of Torres (2006). According to the author, the highest levels of corrosion were with voltages of 70V and test 
time of 40 hours. Subsequently, as we were searching for a worst case scenario of corrosion, it was decided to adopt the ddp 70V and a test time of 48 hours after the curing of the concrete.

The equipments used to obtain constant voltage of $70 \mathrm{~V}$ were direct current sources. The samples of the test piece were connected to a power source, as shown in Figure 1, forming an electrical circuit.

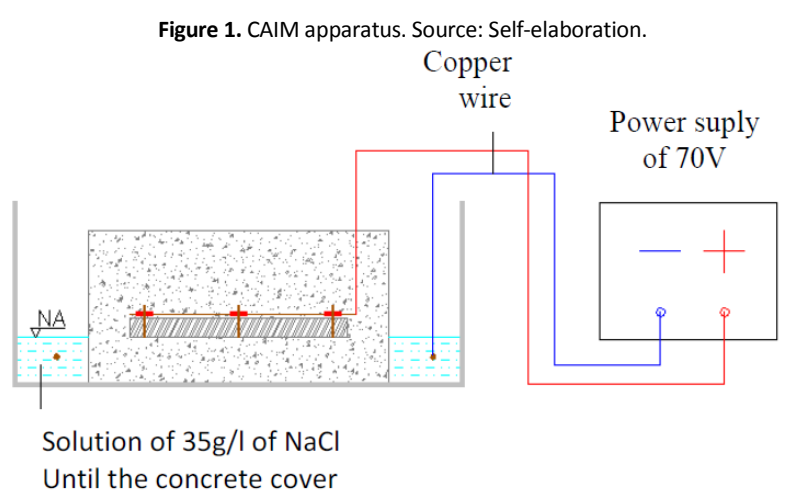

The solution where the prism was partially immersed consists of $35 \mathrm{~g} / \mathrm{I} \mathrm{NaCl}$, similar concentration to that found in the Atlantic Ocean. The height immersion corresponds to the concrete cover in order to simulate the access of moisture and oxygen.

The copper wire is positioned on the surface of the bar without it being in contact with the wire. At the test moment, the wire that is on the bar is connected to the positive pole of the source acting as anode in the electrochemical process, since the negative pole of the power supply is connected to the other wire and this is connected submerged in the solution acting as the cathode in the electrochemical process. Table 5 shows the variables analyzed by the CAIM test.

Table 5. Analyzed variables. Source: Self-elaboration.

\begin{tabular}{|c|c|c|c|c|}
\hline $\mathrm{w} / \mathrm{c}$ ratio & Tension (V) & Time (h) & Variables & $\mathrm{n}^{\circ}$ of samples \\
\hline \multirow[t]{2}{*}{0.30} & 70 & 48 & reference & 3 \\
\hline & & & $\begin{array}{l}\text { hot-dip } \\
\text { galvanic }\end{array}$ & 3 \\
\hline \multirow[t]{2}{*}{0.40} & 70 & 48 & reference & 3 \\
\hline & & & $\begin{array}{l}\text { hot-dip } \\
\text { galvanic }\end{array}$ & 3 \\
\hline \multirow[t]{2}{*}{0.50} & 70 & 48 & reference & 3 \\
\hline & & & $\begin{array}{l}\text { hot-dip } \\
\text { galvanic }\end{array}$ & 3 \\
\hline \multirow[t]{2}{*}{0.60} & 70 & 48 & reference & 3 \\
\hline & & & $\begin{array}{l}\text { hot-dip } \\
\text { galvanic }\end{array}$ & 3 \\
\hline
\end{tabular}

Results and Considerations

The results of the compressive strength of the concrete and the loss in mass of steel bars within the prisms, after the accelerated corrosion test, are shown below.

\section{Compressive strength}

The results of the tests to characterize the strength to axial compression of the samples at 7 and 28 days are shown in Table 6.

\begin{tabular}{ccc} 
Table 6. Results of potential strength compressive of samples. Source: Self-elaboration. \\
\cline { 1 - 1 } Age & Composition & $\begin{array}{c}\text { Potential strength } \\
\text { compressive (MPa) }\end{array}$ \\
\hline 7 days & $1: 03$ & 28.8 \\
$1: 04$ & 26.9 \\
$1: 05$ & 21.4 \\
$1: 06$ & 14.3
\end{tabular}




$\begin{array}{lll}28 \text { days } & 1: 03 & 46.0 \\ & 1: 04 & 34.9 \\ & 1: 05 & 29.2 \\ 1: 06 & 24.5\end{array}$

All traces demonstrated an increase of compressive strength between 7 and 28 days, which is expected, besides the natural evolution of poor traces to rich traces. Therefore, the results of the compressive strength of the samples were satisfactory. The results are also in accordance with conventional applications.

\section{Loss in mass}

The amount of loss in mass is based on the degree of corrosion, whose formula is given by equation 1.

$$
G C(\%)=\frac{\text { mcons }}{\text { minic }} * 100
$$

Where:

$\mathrm{GC}=$ degree of corrosion (\%)

mcons = consumed mass in corrosion process (grams)

minic $=$ initial mass of the reinforcement bar (grams)

The results of loss in mass for each trace, for each type of protection, are disposed in Table 7.

\begin{tabular}{|c|c|c|c|c|}
\hline Prism & $\begin{array}{l}w / c \\
\text { ratio }\end{array}$ & Mass loss (\%) & $\begin{array}{c}\text { Average mass } \\
\text { loss (\%) }\end{array}$ & $\begin{array}{l}\text { Reduction of mass loss } \\
\text { comparing with } \\
\text { standard prism of } \\
\text { same } w / c(\%)\end{array}$ \\
\hline \multirow[t]{12}{*}{ Reference } & 0.30 & 1.89 & 2.00 & - \\
\hline & & 2.58 & & \\
\hline & & 1.54 & & \\
\hline & 0.40 & 7.05 & 7.07 & - \\
\hline & & 6.46 & & \\
\hline & & 7.71 & & \\
\hline & 0.50 & 8.08 & 7.34 & - \\
\hline & & 6.58 & & \\
\hline & & 7.36 & & \\
\hline & 0.60 & 10.45 & 10.33 & - \\
\hline & & 10.61 & & \\
\hline & & 9.94 & & \\
\hline \multirow{12}{*}{$\begin{array}{l}\text { Hot-dip } \\
\text { galvanized }\end{array}$} & 0.30 & 0.48 & 0.59 & 70.5 \\
\hline & & 0.71 & & \\
\hline & & 0.59 & & \\
\hline & 0.40 & 4.82 & 4.25 & 39.9 \\
\hline & & 3.88 & & \\
\hline & & 4.03 & & \\
\hline & 0.50 & 6.83 & 5.11 & 30.4 \\
\hline & & 5.03 & & \\
\hline & & 3.48 & & \\
\hline & 0.60 & 9.19 & 9.20 & 10.9 \\
\hline & & 9.13 & & \\
\hline & & 9.26 & & \\
\hline
\end{tabular}

It is noticeable that the loss in mass decreases as lower is the water/cement ratio, showing that the better the quality of the concrete the lower is the possibility of the reinforcement oxidation.

This fact is already known and expected, even highlighted by standards that consider the design of structures durability, such as NBR 6118 (ABNT, 2014), which determines the reduction of water / cement ratio when environmental aggression is greater. Then, it is possible to relate the loss in mass with the resistivity, since the decrease of $\mathrm{w} / \mathrm{c}$ ratio 
results in better compactness of the concrete, thereby reducing the electrolyte present in the voids of concrete, thus reducing the corrosion process.

The reduction of corrosion of conventional bars for hot-dip galvanized was high, especially in lower w / c ratio, reaching $70.5 \%$ for the 1:3 trace. This shows that the less porous the concrete is, the more efficient is the protection by hot-dip galvanizing, because in the poorest traces the bars become more exposed to aggressive agents. Even with extra protection, the situation remains aggressive, breaking the protective coating.

Therefore, it is observed that the hot-dip galvanizing assists in the durability of the reinforced concrete, but it cannot be considered as the only solution. The ideal action is to combine an efficient indirect protection (low w/c ratio) with direct protection (hot-dip galvanizing).

For a better visualization of the loss in mass bond to w/c ratio, and with protection methods, see the results in Figure 2 .

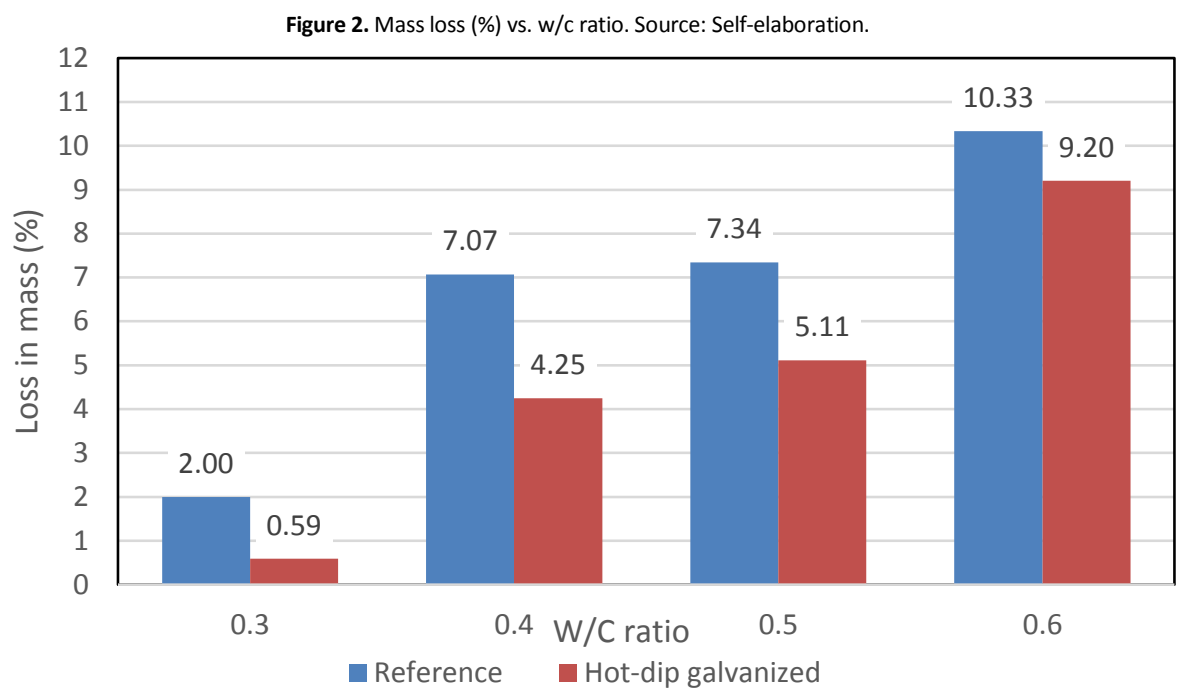

\section{Visual Analysis}

Table 8 illustrates the steel bars after CAIM tests, showing the bars before and after the cleaning of loose oxides, to calculate the measurements of the loss in mass.

Table 8. Steel bars after CAIM tests, showing the bars before and after the cleaning of loose oxides. Source: Self-elaboration. 


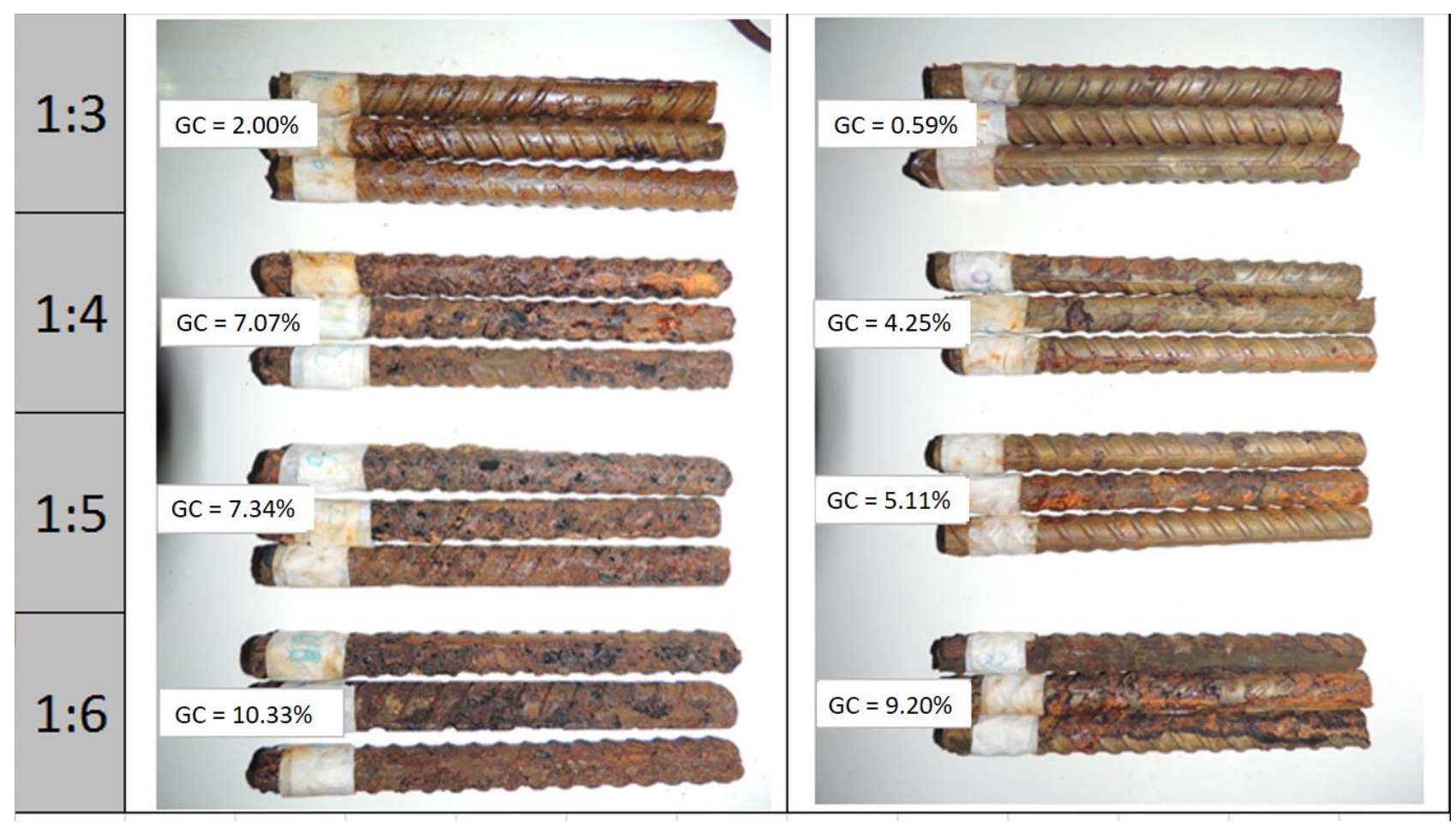

It is possible to visualize the formation of oxy-hydroxides of iron on the reinforcements after the accelerated test, with clear evidence that the corrosion product occupies volumes that are larger than the original steel reinforcement volume, mainly in the bars referential prisms. This is the material that will produce internal pressures causing cracks in the concrete. It is observed that the bars placed in the referential prisms are the most damaged ones.

In the presence of chloride ions, the corrosion form is localized with the formation of pits. One can see evidence of this form of corrosion in the figures of Table 8, confirming what was expected.

There is also evidence of the electrochemical mechanism, with the presence of two partial reactions - the cathodic reaction and anodic reaction. It is noticeable that the anodic reaction, where there is loss of electrons, is evidenced by the presence of pits, whereas the cathodic reaction, where there is gain of electrons, is evidenced by the accumulation of corrosion material.

\section{Dosage diagram}

In conclusion, counting with the gathered results, to correlate the properties the behavioral equations with coefficients of correlation and the dosage diagram were determined allowing the correlation among properties.

The behavioral equations, with the respective correlation coefficients are shown in Table 9.

Table 9. The behavioral equations and the correlation coefficients. Source: Self-elaboration

\begin{tabular}{lccc}
\multicolumn{2}{c}{ Table 9. The behavioral equations and the correlation coefficients. Source: Self-elaboration. } \\
\hline Properties & Behavioral equations & $\mathrm{r}^{2}$ \\
\hline Law of Abrams & 7 days & $f c 7=\frac{62.94}{10.27^{a / c}}$ & 0.91 \\
& 28 days & $f c 28=\frac{83.02}{7.91^{a / c}}$ & 0.99 \\
Law of Lyse & $m=16.617 * a / c-1.783$ & 0.99 \\
Law of Molinari & & $C=\frac{2159}{m+0.8525}$ & 0.99 \\
Mass loss & Reference & LMref $=-2.6149 * f c 28+51.13$ & 0.95
\end{tabular}


It is observed that the correlation coefficients were high, above 0.90 for all properties, which increases the reliability of the tests.

Being the behavioral equations calculated it is possible to plot the dosage diagram, correlating the compressive strength at 28 days with loss in mass and with the w/c ratio, this trace with Unit 1: $\mathrm{m}$, and that, finally, with consumption of cement per cubic meter of concrete. The dosage diagram is a quick way to determine concrete traces from certain required properties. The diagram should be used clockwise, with the loss in mass being the starting point. One can use in counterclockwise sense, but with the consumption of cement as the starting point.

The dosage diagram is shown in Figure 3. In this Table, there is also a dotted showing as an example the determination of a trace with the specification of loss in mass of $5 \%$ at 28 days for the hot-dip galvanized bars. If an accurate calculation is performed, using the behavioral equations, the following parameters will be obtained by this trace: $5 \%$ of loss in mass for hot-dip galvanized bars; 33.1 MPa of compressive strength at 28 days; $0.44 \mathrm{of}$ w/c ratio; Unit trace of 1:m 1:5.60; and $334.5 \mathrm{~kg} / \mathrm{m}^{3}$ of cement consumption per cubic meter. It is observed that the values were very close to those found graphically, showing the effectiveness of this tool. 
Figure 3. Dosage diagram with an example of a specification with $5 \%$ of mass loss for hot-dip galvanized bars. Source: Self-elaboration.

fcj (MPa)

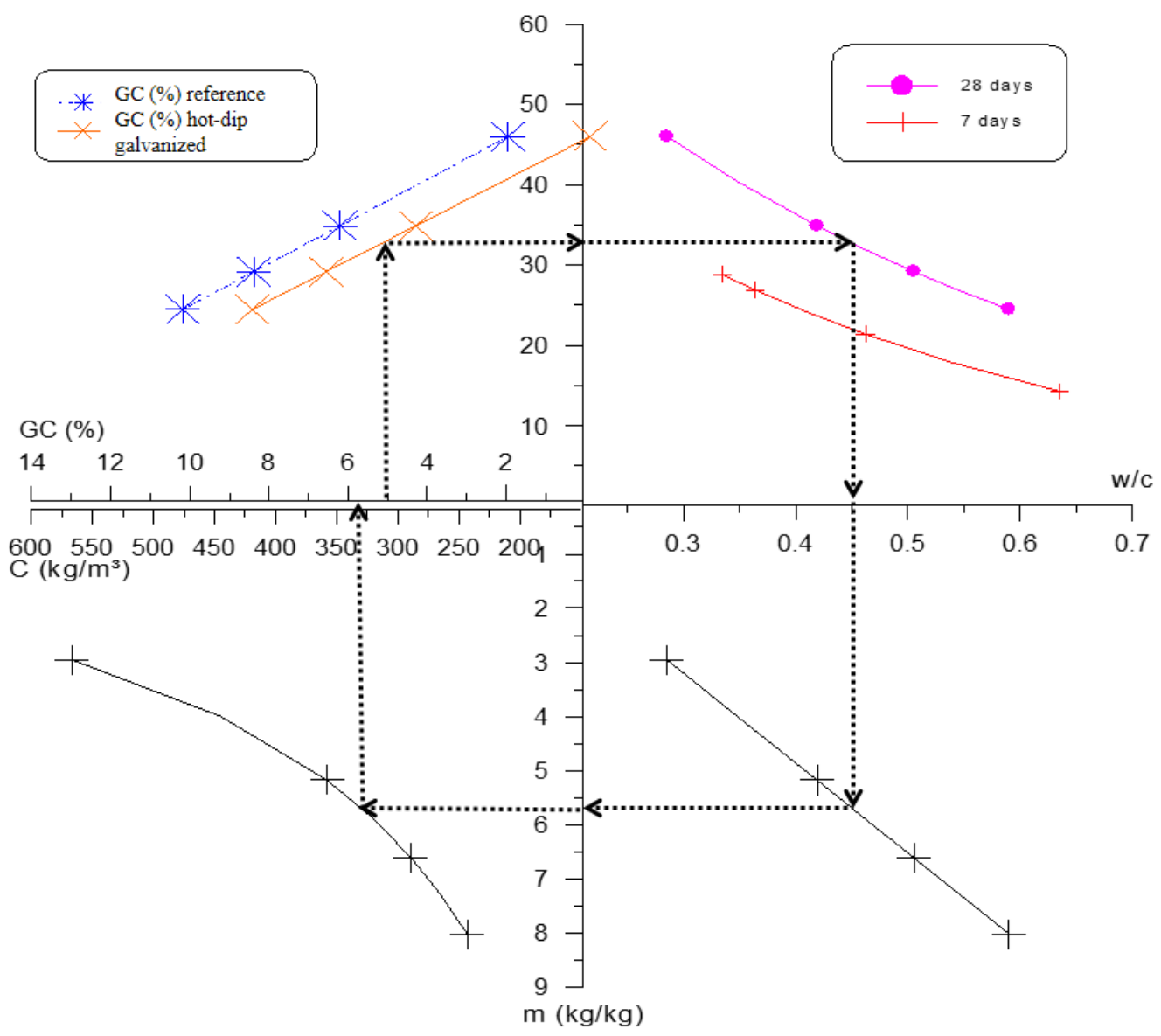

Conclusions

After the experimental part of this paper, it is possible to conclude that the hot-dip galvanizing can be an excellent option for applications with high environmental aggression. It was observed that, for the studied materials, the combination of a direct protective concrete cover thickness with low water / cement ratio, along with an indirect protection of hot-dip galvanizing is the most favorable to increase the durability of reinforced concrete structures. The hot-dip galvanizing method is efficient and provided a reduction of accelerated corrosion, for all studied concrete mixtures, however, their effectiveness increases for traces of higher quality with lower w/c ratio and more resistance to compressive strengths.

It was also possible to determine the behavioral equations and dosage diagram, becoming an effective tool for more effective dosages.

\section{References}

Amaya, J. L., Cornejo, M., Rigail-Cedeno, P. A. \& Eng, D. (2016). Análisis del costo del ciclo de vida del uso de inhibidores de corrosión para la protección de estructuras de hormigón armado. 14th LACCEI International Multi-Conference for Engineering, Education, and Technology: "Engineering Innovations for Global Sustainability", 20-22 July 2016, San José, Costa Rica.

AMN. (2000). NM 23: Cemento portland - Método de determinación de la densidad absoluta. Sao Paulo, Brasil. Asociación Mercosur de Normalización. AMN (2006). NM 45: Aggregates - Determination of the unit weight and air-void contents. Sao Paulo, Brasil. Asociación Mercosur de Normalización.

AMN (2009). NM 52: Agregado fino - Determinación de la densidad relativa y de la densidad relativa aparente. Sao Paulo, Brasil. Asociación Mercosur de Normalización. 
AMN (2009) NM 53: Coarse aggregate - Determination of the bulk specific gravity, apparent specific gravity and water absorption. Sao Paulo, Brasil. Asociación Mercosur de Normalización.

AMN (2001). NM 248: Agregados - Determinación de la composición granulométrica. Sao Paulo, Brasil. Asociación Mercosur de Normalización.

AMN (1998). NM 67: Concrete - Slump test for determination of the consistency. Sao Paulo, Brasil. Asociación Mercosur de Normalización.

ABNT (2014). NBR 6118: Projeto de estruturas de concreto. Procedimento. Rio de Janeiro, Brasil. Associação Brasileira de Normas Técnicas.

ABNR (2013). NBR 15575: Edificações habitacionais - desempenho. Rio de Janeiro, Brasil. Associação Brasileira de Normas Técnicas.

Baltazar-Zamora, M.A., Bandala, E.M., Tello, M.U., Hurtado, G.S., Coca, F.J., Cedano, A.O., Barrios, C.P., Nuñez, R.E., Zambrano, P., Tiburcio, C. \& Calderón, F. (2012). Efficicency of galvanized steel embedded in concrete previously cantamineted with 2, 3 and $4 \%$ of $\mathrm{NaCl}$. Internacional Journal of Electrochemical Science, 7, 2997-3007.

BSI (2003). BS 7543: Guide to durability of buildings and building elements, products and components. London. British Standards Institution.

Faustino, P.; Brás, A. \& Ripper, T. (2015). The effect of corrosion inhibitors on the modelling of design lifetime of RC structures. Materials and Structures, $48,(5), 1303-1319$.

Figueiredo, E.P. \& Meira, G. (2013). Corrosión de armadura de estructuras de hormigón. Mérida, México. Alconpat. Boletim técnico no6.

Gonçalves, A., Andrade, C. \& Castellote, M. (1997). Manual de Inspección, Evaluación y Diagnóstico de Corrosión en Estructuras de Concreto Armado. Rio de Janeiro, Brasil. Red Durar, CYTED Program.

Graeff, A. (2007). Avaliação experimental e modelagem dos efeitos estruturais da propagação da corrosão em elementos de concreto. Dissertação (Mestrado em Engenharia Civil) - Programa de Pós-Graduação em Engenharia Civil: PPGEC/UFRGS, Porto Alegre, Brasil.

Grochoski, M. \& Helene, P. R. L. (2008). Sistemas de reparo para estruturas e concreto com corrosão de armaduras. Boletim Técnico da Escola Politécnica da USP, Departamento de Engenharia de Construção Civil. São Paulo, Brasil.

IS (2012). ISO 9223: Corrosion of metals and alloys - corrosivity of atmospheres - classification, determination and estimation. Genève, Switzerland. International Organization for Standardization.

LIMA, R. C. A. (2005). Investigação do comportamento de concretos em temperaturas elevadas. Tese (Doutorado em Engenharia Civil) - Programa de Pós Graduação em Engenharia Civil: PPGEC/UFRGS, Porto Alegre, Brasil.

Maldonado, L., Pech-Canul, M. A. \& Alhassan, Safaa. (2006). Corrosion of zinc-coated reinforcing bars in tropical humid marine environments. AntiCorrosion Methods and Materials, 53(6), 357-361.

Pacheco, F. (2016). Investigação da relação entre os parâmetros de projeto das estruturas de concreto armado visando à durabilidade. Dissertação apresentada ao programa de pós graduação em engenharia civil da UNISINOS, São Leopoldo, Brasil.

Pannoni, F. D. (2011). Princípios da proteção de estruturas metálicas em situação de corrosão e incêndio. In: Coletânea do uso do aço. Porto Alegre, Brasil. Gerdau.

Poursaee, A. (2016). Corrosion of Steel in Concrete Structures. Woodhead Publishing, 2016. Elsevier.

Possan, E. \& Andrade, J. J. de O. (2014). Markov Chains and reliability analysis for reinforced concrete structure service life. Materials Research, 17(3), 593-602.

Triana, V., Lizarazo-Marriaga, J. \& Flórez, J.O. (2013). Steel corrosion assessment by electrochemical impedance on metakaolin blended mortars. Materials Research, 16(6), 1457-1464.

Torres, A. S. (2006). Avaliação da sensibilidade do ensaio CAIM - corrosão acelerado por imersão modificada - frente ao processo de corrosão. Dissertação (Mestrado em Engenharia Civil) - Programa de Pós Graduação em Engenharia Civil: PPGEC/UFRGS, Porto Alegre, Brasil.

Tutikian, B. \& Ortolan, V. (2014). Comparação da resistência à compressão, da perda de massa e visual entre inibidores de corrosão para prismas de concreto armado. Ciência \& Engenharia, 23(1), 01-08.

Tutikian, B. F., \& Helene, P. R. L. (2011). Dosagem de concretos de cimento Portland. In: Livro Concreto: Ciência e Tecnologia. Capítulo 12. São Paulo: IBRACON.

Yeomens, S.R. (2004). Galvanized steel reinforcement in concrete: an overview. Elsevier.

Yoo, Y., Nam, T., Choi, Y., Kim, J. \& Chung, L. (2011). A galvanic sensor system for detecting the corrosion damage of the steel embedded in concrete structures: laboratory tests to determine the cathodic protection and stray-current. Metals and Materials International, 17(4), 623-629.

Vayas, I. \& Iliopoulos, A. (2014). Design of steel-concrete composite bridges to Eurocodes. New York, Taylor \& Francis Group.

Verma, S.K., Bhadauria, S.S. \& Akhtar, S. (2014). Monitoring corrosion of Steel bars in reinforced concrete structures. The Scientific World Journal, 2014, 9. http://dx.doi.org/10.1155/2014/957904. 